\title{
The Effect of Multimedia-Based Learning on the Concept Learning Levels and Attitudes of Students ${ }^{1}$
}

\section{H. Ömer BEYDOĞAN² \\ Zeynel HAYRAN ${ }^{3}$}

\author{
Suggested Citation: \\ Beydogan, H. Ö. \& Hayran, Z. (2015). The effect of multimedia-based learning on the \\ concept learning levels and attitudes of students. Eurasian Journal of \\ Educational Research, 60, 261-280 \\ Doi: 10.14689 /ejer.2015.60.14
}

\begin{abstract}
Problem Statement: Rich stimuli received by sensory organs such as vision, hearing, and touch are important elements that affect an individual's perception, identification, classification, and conceptualization of the external world. In primary education, since students perform conceptual abstraction based upon concrete characteristics, when they lack sufficient knowledge of and experience with these characteristics, they encounter serious difficulty with performing conceptual abstraction and using concepts according to their functions.
\end{abstract}

Purpose of the Study: This study examined the impact of teaching based on rich stimuli upon students' effective use of conceptualization processes and whether multimedia-based learning can change the attitudes of students toward learning.

Methods: A 28-item concept test (r.703) and 28-item attitude scale (r.87) were developed for a unit titled "Let's Get Acquainted with Our Region" of a social studies course. The levels of students' learning concepts covered in the unit and their use in accordance with their functions were examined via a pretest-posttest model. Students in the experimental group were taught 24 concepts covered in the unit through multimediabased teaching activities for 6 weeks. In the control group, the same concepts were taught with teaching activities already established for the

${ }^{1}$ This study was supported within the framework of Ahi Evran University Scientific Research Projects, no. SBA-11-08.

${ }^{2}$ Corresponding author: Ahi Evran University, Faculty of Education, Department of Educational Sciences, hobeydogan@gmail.com

${ }^{3}$ Ahi Evran University, Faculty of Education, Department of Teaching Turkish,

zhayran@gmail.com 
unit. Students in the experimental group subjected to multimedia-based teaching were compared with the control group students in terms of how they perceived, distinguished, classified, generalized, and functionally used concepts. An attitude scale was also administered both before and after teaching to determine whether any change occurred in the attitudes of students toward their respective courses. Data analysis involved calculating means and standard deviations, as well as $t$ tests and one-way analysis of variance.

Finding and Results: In terms of identifying and classifying concepts and making inferences through generalization, students in the experimental group showed a significantly positive change in attitude toward the social studies course.

Conclusions and Recommendations: This study highlighted the importance of a balanced use of information channels and the critical role of contextual arrangements in multimedia-based teaching concerning how students use concepts according to their functions at the end of concept-teaching processes. Based on the findings, some recommendations can be made regarding the concept-teaching process, the teaching materials used in the teaching process, and the elimination of deficiencies about concept teaching.

Keywords: Classification, conceptualization, functional use, generalization, identification, rich stimuli

\section{Introduction}

Each person enters this world as an individual biological being, one who receives stimuli from the external world that he or she transfers via sensory organs to the mind. Each sensory organ performs independent processes on the stimuli it receives, meaning that information from sensory organs is initially disordered, unconnected, and meaningless. As a result, association and interpretation occur in the mind. In this context, learning refers to conscious responses to information received from sensory organs. According to sensory integration theory, an individual's participation in the learning process, both physically and in line with sensations, involves many nerve endings stimulated simultaneously and in coordination (Bundy, Lane, \& Murray, 2002; Willis, 2008). As such, interpretation refers to the transferal of chemical changes in stimulated nerve endings to neurons engaged in cognition, the comparison and association of the information with previous experiences, and its rearrangement in cognition. Referred to as perception, this process by which knowledge is constructed in the mind coincides with sensation, meaning that it is exceptionally difficult for objects to be sensed in their entirety (Manocha \& Narang, 2004).

An individual envisages the stimuli that he or she receives in his or her cognitive world and concretizes them via symbolization by means of language. Stimuli associated with objective reality received by sensory organs thus also contribute to 
the process of abstraction, which involves four types. Conceptual abstraction is concrete if it entails directing one's attention to an object, distinguishing it from other objects, and envisaging it; conceptual abstraction is identity related if it encompasses hearing and vision, observing different environments, distinguishing, and recognizing; conceptual abstraction is classificatory if it means making generalizations among multiple similar objects or events and responding accordingly; and conceptual abstraction is formal if it requires identifying, defining, explaining relevant characteristics, distinguishing, and evaluating relevant former characteristics alongside current ones (Klausmeier, 1975). The knowledge acquired in any of these processes is stored in the long-term memory, and when an individual faces new experiences, he or she recalls the concepts (i.e., abstractions) acquired beforehand and uses them in formulating new concepts. Conceptualization includes such processes as sensation, perception, identification, classification, association, generalization, and functional use. In this regard, the skills of perceiving, distinguishing, generalizing, and classifying need to be improved among students in the concept-learning process (Klausmeier, 1976; Merrill \& Tennyson, 1992; Tennyson, 1980).

Abstractions that emerge through mental operations are considered to constitute the primary characteristic of mental functioning. Every concept formed in the human mind refers to something and is part of the hierarchy of concepts, meaning that concepts are stored hierarchically in the mind (Senemoğlu, 2015, pp. 43-44). However, an individual may fail to interpret concepts sufficiently even if he or she experiences the aforesaid processes in enough depth, largely because the concrete characteristics of objects and ideas that the individual acquires via experience play an important role in his or her interpretation of abstract ones (Barsalou, 1999; Barsalou \& Wiemer-Hastings, 2005). For children, abstraction based on the concrete characteristics of objects and ideas is in fact a process of transformation that requires children to rearrange knowledge in their minds. At the stage of transitioning from concrete to abstract characteristics, children thus do not understand the abstract presentation of new knowledge until they internalize it (Piaget, 1974).

Conceptual knowledge is internalized via a bidirectional interaction involving the assimilation and accommodation of realities with the mind. While some individuals assimilate new knowledge rapidly in the interaction process, others exert more effort to integrate, accommodate, and rearrange new knowledge in their minds (Driscoll, 1984; Hartshorn \& Boren, 1990; Heddens, 1986; Sowell, 1974; Sprinthall \& Sprinthall, 1977). This difference occurs because conceptual knowledge based on abstractions is presented differently and with greater qualification than concrete conceptual knowledge (Sebastian \& Elizabeth, 2005). Necessary in this process is multimedia by which individuals can use their sensory organs in balanced ways. With multimedia, conceptual knowledge must be transferred to cognition, coded, and analyzed without causing an overload of sensory channels. If stimuli of rich content is provided, difficulties with identifying, associating, and reconstructing the qualifications of concepts in cognition disappear. By contrast, in environments lacking sufficiently multiple stimuli, many students experience difficulty with 
understanding the contents of concepts and fail to close the gap between the world of thought and the physical world (Bayram, 2004). Researchers have reported that teachers play an important role in filling such gaps in the learning process (Berman \& Friederwitzer, 1983; Heddens, 1986; Sowell, 1989). In this sense, teachers can facilitate students' transition from concrete to abstract thinking by presenting concrete materials via multimedia, enabling students to think logically, and improving their thought processes by exposing them to different examples (Heddens, 1986; Stanic \& McKillip, 1989).

Previous studies have demonstrated that the presentation of verbal information through vocalization but not visualization makes multimedia-based teaching more effective (Gelder \& Vroomen, 1997; Tabbers, Martens, \& van Merriënboer, 2001). This dynamic can be attributed to the fact that verbal information and visual information are processed in two subsystems during cognition: that of the verbal and that of the image. While visuals are analyzed in both verbal and image systems, words and sentences are analyzed in the verbal system only, which augments the effect of images in the text on memory and facilitates a dual coding process.

Sensations perceived by multiple sensory organs add depth to perception and interpretation in cognition. While some individuals can internalize abstract and symbolic concepts thanks to concrete experiences, other who fail to do so regard abstract concepts to be only superficial words and phrases to be memorized instead of evaluating them as part of the perception process. When students are asked to explain a concept within a conceptual category, they demonstrate their understandings based on their personal perceptions and in their own words. However, when students are asked to remember only the process without explaining any conceptual categorization, they confuse concepts and generally forget them.

Students can effectively interact with information based on images, sounds, and words designed in a previously determined sequence at any time and in any order they desire in accordance with their own decisions, as well as analyze stimuli received during interaction and internalize them (Sar1, 1993: 35). By activating multiple sensations in the teaching environment, multimedia contributes to perception, performance, memory, visual memory, visual attention, and motor skills (Stephenson, 2002).

Yet, researchers have also reported that multimedia can negatively affect learning as a result of scientific overload (Gelder \& Vroomen, 1997). As a solution, at least one report has recommended distributing information among sensory channels in balanced ways (Cakmak, 2007). In this study, verbal and visual materials were used together though verbal expression adopted instead of written expression. Visual materials concerning the teaching of attributes of concepts were associated with verbal information, and visuals (e.g., films) were presented through vocalization.

In this sense, the purposes of the present study was to determine how teaching using multimedia-based stimuli affected the competencies of students in identifying, classifying, generalizing, and functionally using concrete and abstract characteristics of concepts, as well as to ascertain whether this process changed the attitudes of 
students toward learning. As such, experiments with multimedia-based teaching environments were necessary. This study was based on the thought that if the gap experienced by students in transitioning from comprehending concrete characteristics to grasping their abstract ones was filled by multimedia, the difficulties experienced by students in transitioning from concrete to abstract thinking could be diminished. In this regard, the study sought to identify the effect of multimedia-based teaching environments on students' learning of concepts covered in the unit "Let's Get Acquainted with Our Region" taught in a fifth-grade social studies course in Turkey. As connected this problem to research sub-problems identify as follows:

1. Is multimedia-based education affects students' competencies of naming, associating, classifying, and generalizing concepts?

2. Is multimedia-based education affects students' competency of using concepts functionally?

3. Is multimedia-based education affects students' attitudes toward lessons?

To such an end, three hypotheses were developed, as follows:

1. Fifth-grade students educated in a multimedia-based teaching environment differ from those taught in an otherwise similar teaching environment in terms of their capability to identify, associate, and classify concepts covered in the unit "Let's Be Acquainted with Our Region" and to make inferences about these concepts through generalizations.

2. Fifth-grade students educated in a multimedia-based teaching environment differ from those taught in an otherwise similar teaching environment in terms of their capability to functionally use concepts covered in the unit "Let's Get Acquainted with Our Region."

3. Multimedia induces a change in the attitudes of students toward the social studies course.

\section{Method}

An experimental model based on a pretest-posttest design involving an experimental and control group was implemented to investigate the effect of multimedia on concept learning. The concept-learning levels of the fifth-grade students' learning concepts with multimedia were compared with the concept acquisition levels of fifth-grade students continuing to learn concepts in the existing, otherwise similar teaching environment.

Design

In this study, multimedia used in teaching 24 concepts covered in the unit "Let's Get Acquainted with Our Region" to fifth graders was the primary variable. To test the hypotheses related to concept-learning levels, the study was conducted on both 
an experimental and control group formed via the random sampling of students in middle schools located in the city center of Kırsehir, Turkey.

Sample

Both the experimental and control groups of students with concept acquisition levels close to one another were formed to test students acquisition of concepts related to the unit "Let's Get Acquainted with Our Region." Messages in the teaching materials developed for the unit were presented to the experimental group so that multiple sensory channels would be used, while the control group was taught according to the existing, otherwise similar teaching approach. Both groups of students were equalized in terms of gender, age, and preliminary knowledge about the concepts covered in the unit. As prescribed in the instructional plan provided by the Turkish Ministry of National Education (MEB), the unit "Let's Get Acquainted with Our Region" was taught to both groups over the course of 5 weeks.

Instruments and Procedure

Developing the concept test. A test involving the functional use of concepts covered in the unit was developed for data collection. Before the test was developed, goals and acquisitions about the teaching unit were reviewed, and a table of specifications was created based on the classification and association of concepts covered in the unit, the description of different semantic structures (e.g., finding appropriate realworld counterparts in terms of content), the association of concepts, and the causeand-effect relationships and inferences about each concept. A 65-question test was prepared to determine the fifth-grade students' levels of learning the concepts covered in the unit "Let's Get Acquainted with Our Region." For each acquisition in the table of specifications, questions of different levels and meanings were prepared.

To ensure the test's validity and reliability, its items were prepared by drawing upon content in the middle schools' curriculum, the social studies textbook, encyclopedias, and journals. Sixty-five multiple-choice questions were prepared according to the above content in accordance with the acquisitions indicated in the table of specifications. All 65 questions were evaluated for their appropriateness to the students and the scope of the unit by three field teachers and three faculty members specialized in assessment and evaluation, curriculum development, and social studies teaching. Twelve questions were removed from the test after this process.

As a pilot study, the 53-question achievement test prepared was administered to a total of 186 students attending seven different schools that did not include students from the experimental and control groups, after which the test was transformed into forms A and B. During item analysis, dysfunctional items were either removed from the measurement tool or corrected and re-administered to be analyzed with 167 students not previously subjected to the tool. Test statistics such as the means, standard deviation, distinctiveness of each item, and reliability estimation were calculated. Based on statistical analyses, the alpha reliability coefficient of 28 
questions with a disc index of at least .28 and proportion correct greater than .45 was found to be .703 . Ultimately, a test of 28 questions was developed.

Developing the Social Studies Course Attitude Scale. The Social Studies Course Attitude Scale (SSCAS) was prepared as a 40-item five-point Likert-type scale consisting of 40 items to determine the attitudes of students toward learning concepts in the social studies course. First, the researchers constructed 40 sentences concerning concepts covered in the course. Second, for these 40 sentences, expert opinion was gathered from three faculty members specialized in assessment and evaluation, curriculum development, and social studies teaching. Third, based on their criticisms and recommendations, the 40-item scale was administered to a group of 310 teachers at middle schools within the scope of the validity and reliability study of the scale. Explanatory factor analysis revealed that scale items could be classified into three subscales: one of items concerning a negative attitude toward the social studies course, another of items concerning a positive attitude toward the course, and the last of items concerning how the course could be conducted more effectively. Results revealed a positive item-scale relationship for all attitude items, which were thus used in the study proper without modification. To determine the scale's reliability, Cronbach's $r$ value was determined, which as .86 indicated high reliability. The reliability coefficient in the final version of the SSCAS was .845, and all scale items were found to be functional and ready for implementation.

\section{Procedure}

Before the course material was taught, the 28-question concept analysis test and 28-item SSCAS were administered to students in the control and experimental groups. To ensure the effective application of the teaching program prepared for the experimental group and the fulfillment of teaching goals, researchers informed the course teacher about concept teaching, the use of technological tools, the order and duration of teaching materials, and the teaching process flow chart.

For both groups, the unit was then taught for 6 weeks (i.e., 18 course hours) in accordance with the curriculum provided by the Turkish MEB. During that period, the unit "Let's Get Acquainted with Our Region" was covered in the control group within the scope of goals and acquisitions given to the teacher.

By contrast, the unit was covered in the experimental group accompanied with multimedia aimed to supplement the teaching program. For both groups, the teaching program was distributed along with the teaching materials prepared by researchers, including concept maps, graphs, puzzles, meaning maps, an activity involving the preparation of relief maps with play dough, and another entailing the concretization of erosion with a cloth, sand, and water, among other activities. The visual materials developed in the teaching process were placed on the classroom board, and small versions of materials were affixed to the students' notebooks. Once the unit was completely taught, the achievement test and SSCAS were readministered to both groups. 
Data Analysis

Within the scope of the analysis of data related to the first, second, and third hypotheses, a concept evaluation test was administered to the control and experimental groups as both a pre- and posttest in order to determine to what degree students understood the concepts in the unit "Let's Be Acquainted with Our Region" covered in the social studies course, as well as to what degree they used those concepts in their actual lives in accordance with their relevant functions. The concept acquisition pretest scores of both groups were recorded and the means and standard deviations of the pre- and posttest scores of the groups calculated. One-way analysis of variance (ANOVA) was conducted in order to reveal any significant difference between posttest scores concerning concept acquisition levels. The level of significance was set at $p<.05$.

Within the scope of the analysis of data related to the third hypothesis, the attitudes of students toward concept learning in the social studies course were targeted by administering the SSCAS to both the control and experimental groups twice: before and after the unit was taught. The means and standard deviations of the pre- and posttest attitude scores of the groups were investigated. Once the unit was completely taught, the attitude levels of the groups were measured, and one-way ANOVA was conducted to reveal any significant difference between scores pre- and posttest. The level of significance was again set at $p<.05$.

\section{Results}

This section examines each the present study's hypotheses one by one. Data are tabulated and provided under the relevant hypothesis.

1. Multimedia-based education affects students' competencies of naming, associating, classifying, and generalizing concepts.

The concept-learning competencies of the experimental group educated in an environment based on multimedia and the control group taught in the existing, otherwise similar teaching environment were calculated based on their scores achieved on the pre- and posttest. Table 1 provides the means, standard deviations, and $t$ values of both groups in accordance with the scores achieved. 
Table 1

Pre and Post-test Means and Standard Deviations of the Groups

\begin{tabular}{llllll}
\hline \multirow{2}{*}{ Group } & \multicolumn{2}{l}{ Pre-test } & \multicolumn{3}{c}{ Post-test } \\
\cline { 2 - 6 } & $n$ & $M$ & $S D$ & $M$ & $S D$ \\
\hline Experimental & 27 & 8.88 & 1.219 & 20.18 & 3.076 \\
\hline Control & 27 & 8.77 & 1.577 & 15.96 & 3.975 \\
\hline
\end{tabular}

To understand whether the difference between the means of the experimental and control groups was statistically significant, one-way ANOVA was performed with the groups' scores, the results of which appear in Table 2.

\section{Table 2.}

The Groups' Levels of Identifying, Classifying, Generalizing, and Functionally Using Concepts

\begin{tabular}{|c|c|c|c|c|c|c|}
\hline Dimension & Source of variance & $\begin{array}{l}\text { Sum of } \\
\text { square }\end{array}$ & $D f$ & $\begin{array}{l}\text { Mean } \\
\text { square }\end{array}$ & $F$ & $P$ \\
\hline \multirow{3}{*}{ Identification } & Among groups & 28.16 & 1 & 28.167 & 16.49 & .000 \\
\hline & Within groups & 88.81 & 52 & 1.708 & & \\
\hline & Total & 116.98 & 53 & & & \\
\hline \multirow{3}{*}{ Classification } & Among groups & 14.51 & 1 & 14.519 & 5.95 & .018 \\
\hline & Within groups & 126.81 & 52 & 2.439 & & \\
\hline & Total & 141.33 & 53 & & & \\
\hline \multirow{3}{*}{ Generalization } & Among groups & 26.74 & 1 & 26.741 & 10.03 & .003 \\
\hline & Within groups & 138.59 & 52 & 2.665 & & \\
\hline & Total & 165.33 & 53 & & & \\
\hline \multirow{3}{*}{ Functional use } & Among groups & 2.66 & 1 & 2.667 & 3.58 & .064 \\
\hline & Within groups & 38.66 & 52 & .744 & & \\
\hline & Total & 41.33 & 53 & & & \\
\hline \multirow[t]{3}{*}{ Total score } & Among groups & 240.66 & 1 & 240.667 & 19.04 & .000 \\
\hline & Within groups & 657.03 & 52 & 12.635 & & \\
\hline & Total & 897.70 & 53 & & & \\
\hline
\end{tabular}


As Table 2 shows, a significant difference emerged between groups in terms of their capability to identify $(\mathrm{F}(1-52)=16.49, p<.05)$, classify $(\mathrm{F}(1-52)=5.95, p<.05)$, and generalize $(\mathrm{F}(1-52)=10.3, p<.05)$ concepts, yet not in terms of functionally using them. A significant difference also emerged between the total scores of the groups achieved in all dimensions $(\mathrm{F}(1-52)=19.04, p<.05)$.

A statistically significant difference in favor of the experimental group was additionally detected between the means of two groups according to identifying, classifying, and generalizing. A $t$ test was conducted to identify the source of difference between the concept-learning levels of students and determine whether the difference between the means of the groups was statistically significant.

2. Multimedia-based education affects students' competency of using concepts functionally.

Table 3.

Means, Standard Deviations, and T Values of The Posttest by Levels of Identifying, Associating, Generalizing, and Functionally Using Concepts

\begin{tabular}{|c|c|c|c|c|c|c|c|}
\hline Concept & Group & $N$ & $M$ & $S D$ & $T$ & $S D$ & $p$ \\
\hline \multirow[t]{2}{*}{ Identification } & Experimental & 27 & 5.74 & 1.095 & \multirow{2}{*}{4.06} & \multirow{2}{*}{52} & \multirow{2}{*}{.000} \\
\hline & Control & 27 & 4.29 & 1.488 & & & \\
\hline \multirow[t]{2}{*}{ Classification } & Experimental & 27 & 5.29 & 1.353 & \multirow{2}{*}{2.44} & \multirow{2}{*}{52} & \multirow{2}{*}{.018} \\
\hline & Control & 27 & 4.25 & 1.745 & & & \\
\hline \multirow[t]{2}{*}{ Generalization } & Experimental & 27 & 6.59 & 1.393 & \multirow{2}{*}{3.16} & \multirow{2}{*}{52} & \multirow{2}{*}{.003} \\
\hline & Control & 27 & 5.18 & 1.840 & & & \\
\hline \multirow[t]{2}{*}{ Functional use } & Experimental & 27 & 2.66 & .832 & \multirow{2}{*}{1.89} & \multirow{2}{*}{52} & \multirow{2}{*}{.064} \\
\hline & Control & 27 & 2.22 & .891 & & & \\
\hline \multirow[t]{2}{*}{ Posttest total } & Experimental & 27 & 20.185 & 3.076 & 4.36 & 52 & .000 \\
\hline & Control & 27 & 15.963 & 3.9757 & & & \\
\hline
\end{tabular}

Table 3 reveals a significant difference in favor of the experimental group in identifying, associating, classifying, and generalizing concepts $(d f=52, p<.05)$, possibly due to multimedia-based teaching. However, no significant difference emerged between the groups in functionally $(d f=52, p<.05)$.

In another study conducted with fifth-grade students, Bulut (2006) detected a significant difference in favor of the concept development method in comparison with a traditional teaching method in terms of students' learning the meanings of 
words and using them appropriately. The present study's results similarly demonstrate that multimedia positively affects students' use of concepts. Multimedia enabled the experimental group to comprehend the attributes of concepts and the relationship between them given in the verbal and visual materials provided. Previous research has suggested that the combination of conceptual characteristics with stimuli helps to form perceptive bonds in categorization (Goldstone, 2000). When an individual determines categorical differences, he or she can distinguish relevant perceptive dimensions and take each as a separate part (Goldstone \& Steyvers, 2001). In fact, the interpretation of even one example of a category based on preliminary knowledge in inter-conceptual association contributes to the formation of a coherent category (Ahn, Brewer, \& Mooney, 1992). Furthermore, when an individual realizes functional rules, he or she decides more easily whether a concept belongs to a particular category (Richards, Goldfarb, Richards, \& Hassen, 1989).

Concept formation is a process that occurs via the discovery of necessary and sufficient characteristics, both concrete and abstract. In this sense, the current study has shown that multimedia aids students in identifying concepts, classifying them according to relevant characteristics, making inferences about them, and reaching generalizations about them. A previous study found a difference, though not statistically significant, in favor of students taught in a multimedia-based learning environment compared with those taught in a traditional classroom environment (Altınış1k, \& Orhan, 2002), while another has indicated that multimedia effects a positive change in the academic achievement of students with low scores (Issa, Cox, \& Killingsworth, 1999). These latter researchers also found out that students did not exert enough effort during activities engaged during the teaching period, perhaps since students were accustomed to teacher-centered teaching and not activities requiring their active participation. Smeets and Mooji (2000) have furthermore reported no difference in the academic achievement of students educated in multimedia-based learning environment compared to that of students taught in a traditional environment. In sum, previous research has revealed in different conditions that teaching conducted in multimedia-based learning environments generally benefits students' academic achievement.

3. Multimedia-based education affects students' attitudes toward lessons. 
Table 4.

The Groups' Pre- and Posttest Attitude Scores

\begin{tabular}{llllll}
\hline Source of variance & Sum of square & $d f$ & Mean square & $F$ & $p$ \\
\hline Among groups & 439.185 & 1 & 439.185 & 4.698 & .035 \\
Within groups & 4860.963 & 52 & 93.480 & & \\
Total & 5300.148 & 53 & & & \\
\hline
\end{tabular}

As shown in Table 4 , the difference in means $(F=4.698)$ by one-way ANOVA with the pre- and post-attitude scores of students taught in a multimedia-based learning environment and those not was greater than 4.08 , the $F$ table value $(d f=52, p$ $<.05)$.

A range of researchers have argued that multimedia positively affects the attitudes of students toward courses. Altınısık \& Orhan (2002), Woodrow and Mayer-Smith (2000), Mayer-Smith \& Pedretti (2000) and Geban, Ertepinar, Yilmaz, Altın and Sahbaz (1994) have all reported that teaching in multimedia-based learning environments garners more positive attitudes of students toward the course compared to teaching conducted in more traditional environments.

The present study's findings indicate that multimedia benefited the attitudes of students toward the social studies course. The influence of teaching conducted in a multimedia-based learning environment upon the important dimension of attitude in such a short time is attributable to the fact that the information load offered to students via multimedia was distributed among sensory channels in a balanced manner. The findings also show that the study affected the attitudes of students toward the social studies course though the study period lasted only 6 weeks and covered only one unit. To reach more viable conclusions about the effect of multimedia upon attitude, controlled studies should be conducted over a longer period. The findings of the study are also limited to the classes in which the study was conducted and to the environments in which the concepts of the relevant unit were taught.

\section{Discussion and Conclusion}

Each individual constructs concepts in his or her mind from experience. People perceive and reconstruct sensations received by multiple sensory organs in the concept-formation process, and they attribute meanings to the concepts constructed by way of language. Every meaning attributed includes concrete experiences and abstractions formed based on those same concrete experiences. Concepts are thus cognitive products bearing both concrete and abstract characteristics that emerge as a product of both language and the power of the individual's thinking. Research has suggested that individuals can fail to develop all features of the abstract operations 
stage by themselves; even if they become cognitively ready for abstract operations, they can complete such development only when they receive stimuli and incentives from their environments (Cengelci, 1996). When individuals feel alienated from the community in which they live because they think logically, they distance themselves from such thought. In the concept-learning process, students therefore need to be supported by multimedia and integrated into the process logically and emotionally. This process requires analyzing concepts well, demonstrating the relationships between them, understanding conceptual content through generalizations, and using acquired knowledge in different fields. The arrangement of concepts in the mind is also of vital importance in terms of the quality of education.

In the conceptualization process, the fulfillment of relevant functions by cognition mostly depends on the proper, adequate, and quintessential delivery of stimuli received by sensory channels. This process can be efficiently used in the learningteaching process yet only with a balanced distribution of stimuli among sensory channels and without overload on any channel. Using knowledge with a balanced distribution among different sensory channels in the learning-teaching process is called multimedia-based education.

In this context, the present study sought to reveal how students learned concepts covered in a single unit in a social studies course differently in a multimedia-based educational environment and the existing, otherwise similar environment, as well as differences among the attitudes of those students toward the course.

Among discernable conclusions, a statistically significant difference between test questions answered correctly about identifying, classifying, abstracting, and associating concepts with their daily lives favors students taught in a multimediabased learning environment over those taught in the existing, otherwise similar environment. Another significant difference in attitude scores favors multimediabased education over education in the existing classroom environment.

These conclusions suggest that students' functional use of concepts depends on their capability to distinguish concepts semantically. In concept teaching, the semantic dimension of concepts may be provided first, followed by suitable examples concerning their use in different situations. The concept-teaching process may proceed to functional use based on students' experiences following activities involving the identification and association of concepts and making inferences about them.

To enable the introduction of more effective learning experiences concerning concept teaching, teachers should be informed about new developments in concept teaching, the use of information technologies, and how to appropriately prepare teaching materials to students' acquisition of necessary knowledge and skills.

If concepts are taught completely and perfectly through multimedia, more correct generalizations could be produced. To optimize this process, the ingredients of generalizations should be explained and emphasis placed on the sub-concepts suggested by the generalizations. Furthermore, the analyses of concepts covered in a 
particular course should be performed by domain experts, whereby such concepts can be made available for use by teachers.

Based on the present study's findings, research aimed at multidimensional inferences should be conducted in disciplines other than social studies regarding the functionality of concept teaching and the effective use of multimedia, and the effects of multimedia-based practices on learning and student attitudes in other courses should be examined. The comparison of results gained through such examination could contribute to improving concept teaching and our understanding of thinking processes.

\section{References}

Ahn, W., Brewer, W. F., \& Mooney, R. J. (1992). Schema acquisition from a single example. Journal of Experimental Psychology: Learning, Memory, and Cognition, 18, 391-412.

Altınısık, S., \& Orhan, F. (2002). Sosyal bilgiler dersinde çoklu ortamın ogrencilerin akademik basarıları ve derse karsı tutumları üzerine etkisi [The effects of multimedia learning environments on students' attitudes and achievement in social studies]. Hacettepe Universitesi, Egitim Fakultesi Dergisi, 23, 4-49.

Barsalou, L. W. (1999). Perceptual symbol system. Behavioral and Brain Sciences, 22, $577-660$.

Barsalou, L. W., \& Wiemer-Hastings, K. (2005). Situating abstract concepts. In D. Pecher \& R. A. Zwaan (Eds.), The grounding of cognition: The role of perception and action in memory, language, and thinking (pp. 129-163). Cambridge: Cambridge University Press.

Bayram, S. (2004). The effect of instruction with concrete models on eighth grade students' geometry achievement and attitudes toward geometry (Unpublished doctoral thesis). Middle East Technical University, Ankara, Turkey.

Berman, B., \& Friederwitzer, F. J. (1983). Teaching fractions without numbers. School Science and Mathematics, 83(1), 77-82.

Bulut, P. T. (2006). Kavram gelistirme yonteminin 5. sinif ögrencilerinin kelime hazinelerini geliştirmeye etkisi [The effects of concept developing method on improving the vocabulary of $5^{\text {th-grade }}$ students]. Yayımlanmamis yuksek lisans tezi, Gazi Universitesi, Egitim Bilimleri Enstitusu, Ankara.

Bundy, A., Lane, S., \& Murray, E. (2002). Sensory integration (2nd ed.). Philadelphia: PA: F. A. Davis.

Cakmak, E. K. (2007). Çoklu ortamlarda dar bogaz: Asırı bilissel yuklenme. [The bottleneck in multimedia: Cognitive overload]. Gazi Üniversitesi Gazi Egitim Fakultesi Dergisi, 27(2), 1-24. 
Cengelci, B. N. (1996). Gelisimsel olarak kavram ve kategori yapılarının incelenmesi [Examination of developmental concepts and category structure]. Yayımlanmamış doktora tezi, Ege Universitesi Sosyal Bilimler Enstitusu, Izmir.

Driscoll, M. (1984). What research says? Arithmetic Teacher, 31(6), 34-35.

Geban, O., Ertepınar, H., Yılmaz, G., Altın, A., \& Sahbaz, F. (1994). Bilgisayar destekli egitimin öğrencilerin fen bilgisi basarılarına ve fen bilgisi ilgilerine etkisi [The effect of computer-aided instruction on student achievement and attitudes toward science]. Birinci Ulusal Fen Bilimleri Egitimi Sempozyumu Bildiri Ozetleri Kitabı. Izmir: Dokuz Eylul Üniversitesi.

Gelder, B., \& Vroomen, J. (1997). Modality effects in immediate recall of verbal and non-verbal information. Psychology Press, 9(1), 97-110.

Goldstone, R. L., \& Steyvers, M. (2001). The sensitization and differentiation of dimensions during category learning. Journal of Experimental Psychology: General, 130, 116-139.

Goldstone, R. L. (2000). Unitization during category learning. Journal of Experimental Psychology: Human Perception and Performance, 26, 86-112.

Hartshorn, R., \& Boren, S. (1990). Experimental learning of mathematics: Using manipulatives. ERIC Digest. (ED 321967).

Heddens, J. W. (1986). Bridging the gap between the concrete and the abstract. Arithmetic Teacher, 33(6), 14-17.

Issa R. R. A., Cox, R. F., \& Killingsworth, C. F. (1999). Impact of multimedia-based instruction on learning and retention. Journal of Computing in Civil Engineering, 13, 281-290.

Klausmeier, H. J. (1975). Conceptual development during the school years. Paper presented at the conference of the American Educational Reserach Association, Washington, DC.

Klausmeier, H. J. (1976). Individually guided education: 1966-1980. Journal of Teacher Education, 27, 199-205.

Merrill, M. D., \& Tennyson, R. D. (1992). Teaching concepts: An instructional design guide. Englewood Cliffs, NJ: Educational Technology.

Manocha, A., \& Narang, D. (2004). Concept development status of rural preschoolers. Journal of Human Ecology, 16(2), 113-118.

Richards, D. D., Goldfarb, J., Richards A. L., \& Hassen, P. (1989). The role of the functionality rule in the categorization of well-defined concepts. Journal of Exerimental Child Psychology, 4(7), 97-115.

Sarı, I. F. (1993). Interaktif multimedya [Interactive multimedia]. Macintosh Dünyası, 34-39. 
Sebastian J. C., \& Elizabeth K. (2005). Warrington abstract and concrete concepts have structurally different presentational frame works, Oxford Journals Medicine Brain, 128(3), 615-627. doi:10.1093/brain/awh349

Senemoglu, N. (2015). Gelisim ögrenme ve ögretim kuramdan uygulamaya [Development, learning, and teaching from theory to practice]. Ankara: Yarg1 Yayınları.

Smeets, G., \& Mooij, T. (2000). Modelling and supporting ICT implementation in secondary schools. Journal of Computers and Education, 36, 265-281.

Sowell, E. (1974). Another look at materials in elementary school mathematics. School Science and Mathematics, 74(3), 207-211.

Sowell, E. (1989). Effects of manipulative materials in mathematics instruction. Journal for Research in Mathematics Education, 20, 498-505.

Sprinthall, R. C., \& Sprinthall, N. A. (1977). Educational psychology: A developmental approach. Boston, MA: Addison-Wesley.

Stanic, G. M. A., \& McKillip, W. D. (1989). Developmental algorithms have place in elementary school mathematics instruction. Arithmetic Teacher, 36(5), 14-16.

Stephenson, J. (2002). Characterization of multisensory environments: Why do teachers use them? Journal of Applied Research in Intellectual Disabilities, 15, 73 90 .

Tabbers, H. K., Martens, R. L., \& van Merriënboer, J. J. G. (2001). The modality effect in multimedia instructions. In J. D. Moore., \& K. Stenning (Eds.), Proceedings of the 23rd annual conference of the Cognitive Science Society (pp. 1024-1029). Mahwah, NJ: Lawrence Erlbaum Associates.

Tennyson, R. D. (1980). Instructional control strategies and content structure as design variables in concept acquisition using computer-based instruction. Journal of Educational Psychology, 72, 525-532.

Willis, J. (2008). How your child learns best: Brain-friendly strategies you can use to ignite your child's learning and increase school success. Naperville, IL: Sourcebooks.

Woodrow, J., Mayer-Smith, J., \& Pedretti, E. (2000). Closing of the gender gap in technology enriched science education: a case study. Computers $\mathcal{E}$ Education, 35(1), 51-63. 


\title{
Çoklu Ortama Dayalı Öğrenmenin Öğrencilerin Kavram Öğrenme Düzeylerine ve Tutumlarına Etkisi
}

\author{
Atıf: \\ Beydogan, H. Ö. \& Hayran, Z. (2015). The effect of multimedia-based learning on the \\ concept learning levels and attitudes of students. Eurasian Journal of \\ Educational Research, 60, 261-280 \\ Doi: 10.14689 /ejer.2015.60.14
}

\section{Özet}

Bireyin dünyayı anlamlandırması, bilişsel olarak kavramlara yüklediği anlama ve kavramları anlamına uygun kullanma yeterliğiyle ilişkilidir. Anlamlandırmada bu denli önemli olan kavramlaştırma süreci, duyum kanallarından gelen uyaranların bilişe hangi yollarla nasıl etkinleştirilerek geldiğine, etkinleştirmenin sembolik sistemde nasıl bir yol izlediğine, uyaranın niteliğine, içinde sunulduğu bağlama ve bireysel değişkenlere bağlıdır. Bilişte varlıkların somut niteliklerinin yanı sıra soyut özellikleri de algılanmaktadır. Varlıkların soyut yanlarını açıklayan soyut kavramlar, somut kavramlara göre çok daha koordineli, çok daha içsel ve çok daha çok ilişkisel özelliklere sahiptir. Öğrenme öğretme sürecinde öğrencilerin, algıladıkları özellikleri adlandırmaları, analojilerden faydalanarak benzer ve farklı yanlarını keşfedip ilişkilendirmeleri, kategorik olarak sınıflamaları, genellemeler yaparak sonuçlar çıkarmaları ve kavramları niteliklerine uygun kullanmaları, onları kavramsal düşünme sürecinde yeterli hale getirir. Bu sürecin etkin kullanımı çevreden destekleyici nitelikte uyaranlar almasına bağlıdır. Öğretim ortamında ise bunun sağlandığı en uygun ortam çoklu öğretim ortamlarıdır. Bu süreçte öğrencinin soyutlamalar yapması, varlıklarım niteliklerini adlandırması, sinıflaması, ilişkilendirmesi, genellemeler yoluyla çıkarımda bulunması ve işlevine uygun kullanması varlıkların niteliklerinin bilişe aktarılma süreciyle ve öğrenme ortamıyla ilgili değişkenlerin ele alınmasını ön plana çıkarmaktadır. Bu düşünceden hareketle varlıkların niteliklerinin algılanması ve bilişe iletilmesinde işe koşulan öğrenme ortamlarının kavramlaştırma sürecine etkisinin incelenmesi hedeflenmiştir. Bu amaçla problem cümlesi ortaokul 5. sınıf öğrencilerinin Sosyal Bilgiler dersi "Bölgemizi Tanıyalım" ünitesinde yer alan kavramları öğrenmelerinde çoklu ortama dayalı öğretimin etkisi nedir? şeklinde yapılandırılmıştır.

Araştırmanın Yöntemi: Araştırmada ortaokul 5. sınıf Sosyal Bilgiler dersi “Bölgemizi Tanıyalım" ünitesinde yer alan 24 kavramın öğretimine mevcut öğretim ortamıyla çoklu öğretim ortamının etkisi karşılaştırılmıştır. Bu amaçla ön test son test modeline dayalı deney ve kontrol grupları oluşturulmuştur. Deney ve kontrol gruplarının ilgili ünitedeki kavramları niteliklerine uygun kullanma düzeyleri ve sosyal bilgiler dersine karşı tutum düzeyleri açısından denkleştirilmiştir.

Araştırmada Kullanılan Ölçme Araçları: Araştırmacılar tarafından geliştirilen kavram testinin madde analizleri sonucu alpha güvenirlik katsayısı .703 testin 
standart sapması 3,004, aritmetik ortalaması 8.831 skewnes $-0,328$ ve kurtosis $-0,668$ ve mean biserial ise 0,595 olan 28 soru yer almıştır. Ölçme aracının ortalama güçlüğü 0.48 ve Kr-20 güvenirliği .73 olarak bulunmuştur. Öğrencilerin Sosyal Bilgiler dersine karşı tutumlarını belirlemek için 28 soruluk tutum ölçeği geliştirilmiştir. 5'li likert tipinde hazırlanan Sosyal Bilgiler Dersi Tutum Ölçeğinin güvenirlik katsayısı $r$.845 bulunmuştur. Açımlayıcı faktör analizi sonucu Kaiser-Meyer-Olkin Measure of Sampling Adequacy 909; Bartlett's Test of Sphericity testi sonucu 378 serbestlik derecesinde Chi-Square 2489,189 olarak hesaplanmıştır. Ölçek üç alt faktörden oluşmuş olup üç faktör toplam varyansın 53,683'nü açıklamaktadır.

Bulgu, Sonuç, Yorum ve Öneriler: Araştırmada uyaran açısından çoklu ortamda kavramları öğrenen öğrencilerle mevcut öğrenme ortamında kavramları öğrenen öğrencilerin ön test ve son test puanları üzerinde tek yönlü varyans analizi yapılmıştır. Kavramları işlevsel kullanmada (F: 19,04); adlandırmada (F: 5,95), sinıflamada (F: 10,03) değerleri tablo F değerinden büyük bulunmuştur. İki grubun aritmetik ortalamaları arasında fark "adlandırma", "sınıflama" ve "genelleme" düzeyinde deney grubunun lehine istatistiksel olarak anlamlı bir fark olduğu göstermektedir. Kavramları "adlandırma", kavramları "birbiriyle ilişkilendirme ve sınıflama", "genellemelere ulaşma" ve kavramları "işlevine uygun kullanma", düzeyleri arasında 52 serbestlik derecesinde $\mathrm{P}<.05$ anlamlılık düzeyinde deney grubu lehine anlamlı bir fark olduğunu göstermektedir. Kavramları çoklu ortamda öğrenen öğrencilerle mevcut sınıf ortaminda öğrenen öğrencilerin Sosyal Bilgiler dersine karşı tutumları arasında deney grubu lehine anlamlı bir ve farklılı̆̆ın olduğu görülmektedir.

Kavramların niteliklerinin öğretiminde çoklu ortamın daha etkin olduğu, bilginin birden fazla duyum kanalına dengeli yüklenmesinin öğrencilerin kavramları adlandırma, sınıflama, genelleme yeterliklerini olumlu yönde etkilemektedir. Kavramlaştırma sürecinde bilişin işlevini yerine getirebilmesi büyük ölçüde duyum kanallarından gelen uyaranları etkili, doğru ve yeterli düzeyde bilişe aktarılmasına yardım etmektedir. Kavramların somut ve soyut yönlerine ilişkin özelliklerini keşfetmelerini ve anlamlarını artırdığı anlaşılmaktadır. Öğrenme-öğretme sürecinde bilginin duyum kanallarına aşırı yüklenmeden dengeli dağıtılarak kullanılması çoklu ögretim ortamında başarıyı artırmaktadır.

Sonuç olarak, uyaran zenginliği içeren ortamlara öğrencilerin hem analitik ve hem de bütüncül öğrenmelerini sağlamakta, öğrendikleri arasında bağ kurmalarını kolaylaştırmaktadır. Çoklu ortamlardan gelen uyaranlar çocuklarda, kavramların niteliklerini algılamayı kolaylaştırdığı gibi daha kısa sürede de olsa öğrencilerin derse karşı tutumlarında iyileşmeye yol açmaktadır. Öğrenciler içinde yaşadıkları çevrede kullanılan sözcükleri kullanarak kavramları adlandırır, birbiriyle ilişkilendirir yeni çıkarımlarda ve genellemelerde bulunur, kavrama yeni boyutlar katarak içeriğe uygun anlamları birbirine bağlar.

Bu araştırmanın bulgularına dayalı olarak, aşağıdaki öneriler dile getirilmiştir. 
1. Öğretmenlerin kavram öğretiminde öğrencilerine daha etkili öğrenme yaşantıları sağlayabilmeleri için, kavram öğretimi, bilişim teknolojileri, öğretim materyali hazırlama gibi yeterlikleri edinmeleri sağlanabilir

2. Öğretmenlere kavram öğretim sürecinde, öğretim teknolojilerini ve öğretim materyallerinin etkin kullanmaları için hizmet içi eğitim verilebilir.

3. Elde edilen bulguların farklı disiplin alanlarındaki kavramların öğretimindeki işlevselliği gözden geçirilerek çoklu ortamın farklı disiplin alanlarında etkin kullanılabilirliğine ilişkin yeni araştırmalar teşvik edilebilir. Yapılacak yeni araştırmaların, uzun süreli araştırmalara dönüştürülerek analitik sonuçlar elde edilebilir.

4. Ders içeriklerinde yer alan kavramların, kavram analizleri alan uzmanlarınca yapılarak ders kitaplarında öğretmenlerin kullanabilecekleri hale getirilebilir.

5. Öğrencilerin kavramları işlevsel kullanmaları, kavramları anlamsal yönden ayırt etmelerine bağlıdır. Kavramların önce kavramsal anlam boyutu verilip sonra kavramların farklı şekillerde kullanımı için uygun örnekler verilebilir. Kavram öğretim süreci kavramları adlandırma, ilişkilendirme ve çıkarım yapma etkinliklerinden sonra, Öğrenci yaşantılarına dayalı işlevsel kullanımıma geçilebilir

6. Uyaran zenginliği içeren ortamlara dayalı uygulamaların diğer ders1erdeki öğrenmeler ve öğrenci tutumları üzerindeki etkileri incelenerek sonuçlar karşılaştırmalı incelenebilir. Elde edilen bulgular kavram öğretimi ve düşünme sürecinin geliştirilmesi noktasında kullanılabilir.

Anahtar kavramlar: sınıflandırma, kavramsallaştırma, işlevsel kullanım, genelleme, belirleme, çoklu uyaran. 
